\title{
FUNGAL CONTAMINATION IN POULTRY WASTE DURING THE INDUSTRIAL PROCESSING
}

\section{ZANIECZYSZCZENIE MYKOLOGICZNE W PRZEROBOWEJ MASIE ODPADOWEJ Z PRZEMYSŁU DROBIARSKIEGO}

Department of Chemistry, Microbiology and Biotechnology of Environment, West Pomeranian

University of Technology, Szczecin, Poland

\begin{abstract}
Streszczenie. Przemysł drobiarski produkuje duże ilości odpadów, które obejmują odpady stałe i ścieki. Przeprowadzono liczne badania nad zanieczyszczeniem mikrobiologicznym w różnych etapach hodowli i przetwórstwa drobiu. Niewiele jest jednak doniesień dotyczących zanieczyszczeń mykologicznych w różnych etapach zagospodarowania odpadów z przemysłu drobiarskiego. Celem badań było analiza mykologiczna różnych odpadów drobiarskich, m.in. rodzajów piór po uboju, szlamu, osadu biologicznego i kompostu. Próbki pobierano w kilku terminach w latach 2015-2016. Izolację grzybów przeprowadzono metodą seryjnego rozcieńczania i posiewu na podłożu RBA, uzupełnionym antybiotykiem. Identyfikację grzybów przeprowadzono mikroskopowo i genetycznie (gen RNA z rybosomalnym genem $18 \mathrm{~S}$ ). Liczba grzybów (jtk $\cdot \mathrm{g}^{-1} \mathrm{~s}$.m.) wyizolowanych z piór kurcząt i gęsi wynosiła $10^{3}-10^{4}$, z piór kaczych i indyczych $-10^{6}-10^{7}, z$ kompostu $-10^{3}-10^{5}$, ze szlamu - $10^{4}$, a $z$ osadu biologicznego $-10^{4}-10^{6}$. W wyniku przeprowadzonej analizy stwierdzono zależność między liczebnością grzybów z różnych materiałów odpadowych, pobranych w zmiennych warunkach, a miejscem ich pochodzenia.
\end{abstract}

Key words: fungi, poultry waste.

Słowa kluczowe: grzyby, odpady drobiowe.

\section{INTRODUCTION}

Poultry is one of the most intensively reared domesticated species and one of the most developed and profitable animal production industry (Al-Jamaien et al. 2013; Opara et al. 2014). The poultry industry produces large amounts of waste that includes solids and liquids. The solid waste consists of bedding materials, excreta (manure), feed, feathers, hatchery waste (empty shells, infertile eggs, dead embryos and late hatchlings), sludge, abattoir waste (offals, blood, feathers and condemned carcasses) and dead birds (Moreki and Chiripasi 2011; Adedayo 2012). All poultry wastes have to be well managed to minimize environmental hazards originated from the poultry operations. Especially, evaluation of the chicken manure is one of top priority issues for poultry production sector (Unal et al. 2015).

Poultry waste materials, including litter and dead birds, must be properly managed to ensure beneficial use and to prevent adverse effects on the environment and poultry health. Litter

Corresponding author - Adres do korespondencji: Krystyna Cybulska, Department of Chemistry, Microbiology and Biotechnology of Environment, West Pomeranian University of Technology, Szczecin, Juliusza Słowackiego st. 17, 71-434 Szczecin, Poland, e-mail: krystyna.cybulska@zut.edu.pl 
should not be reused when a disease outbreak occurs in a flock (Anne 2007). Poultry litter may contain pathogenic microorganisms (Kim et al. 2012), drug residues and hard or metallic objects that are injurious to crops, poultry, humans and other domestic animals. Poultry waste is usually a combination of poultry bird feces, urine, saw dust and remnants of animal feeds, drugs and pesticides (Asaniyan 2007; Musa et al. 2009; Wilkinson 2011; Adedayo 2012; Musa et al. 2012).

Fungal infections are common in all kinds of poultry, but are less prevalent as compared to bacterial and viral infections. Fungi are eukaryotic organisms, comprising of both yeasts and moulds. They cause significant economic losses to the poultry industry either due to their direct infectious nature or due to production of mycotoxins resulting in high morbidity and mortality, especially in young birds and cause stunted growth, diarrhea, and fatal encephalitis (Singh et al. 2012; Grenier and Applegate 2013). Seasonal variation play important role in spread of fungal infections with predominance during summer and presence of fungi in the poultry litter material during autumn make the eradication difficult (Soliman et al. 2009; Ashwathanarayana and Raja 2016). Exposure to certain fungi is known to produce adverse human health effects through three specific mechanisms the first generation of a harmful immune response such as allergy or hypersensitivity pneumonitis, second direct infection by fungal organism, and third toxic irritant effects from mold by-products such as mycotoxins (Adams et al. 1993; Bush et al. 2006). Fungi are major causes of morbidity and mortality in the world today. Yeasts and molds are found in meat and poultry products before spoilage. Mold species include Cladosporium, Sporotrichum, Geotrichum, Penicillium and Mucor while yeasts species include Candida spp., Cryptococcus spp. and Rhodotorula spp. (Dave and Ghaly 2011). Fungi are found in diverse places depending on environmental conditions and nutritional availability in the soil. Most of the fungi are saprophytic in nature, some are symbiotic and some are parasitic causing infections in plants and animals. Fungi can cause a number of different types of illness through the production of spores. The fungal species most often encountered with intoxications belong primarily to five genera: Alternaria, Aspergillus, Cladosporium, Fusarium, and Penicillium. Other genera, including Chaetomium, Claviceps, Diplodia, Myrothecium, Phoma, Phomopsis, Pithomyces and Strachybotrys, also contain mycotoxic fungi. These molds produce many different toxic compounds but not all isolates of the same species produce toxins (Cole et al. 2003; Brase et al. 2009).

\section{MATERIAL AND METHODS}

The present paper deals with various waste materials from poultry industry at different stages of their management subjected to analysis of mycological contamination (Table 1): feathers from slaughtered poultry (chicken, duck, goose, and turkey), sediment from the centrifuge, sludge from liquid waste reservoir, and poultry compost. These materials originated from three poultry slaughter houses localized in Western Poland. Samples were collected during 12 months at different time intervals. Due to restricted availability and uneven supplies, combinations of analyzed samples varied. The analysis was done in 3 replications. The RBA medium (Rose Bengal Agar) with streptomycin was used to count the moulds (Downes and Ito 2001). Cultures were incubated at $23-24^{\circ} \mathrm{C}$ for $4-5$ days, and then grown colonies were 
counted and results were expressed in cfu per $1 \mathrm{~g}$ of waste dry matter. Identification method of the most common units was preceded by microscopic and genetic analysis $18 \mathrm{~S}$ ribosomal RNA gene. Achieved results were computed applying Statistica 12 software.

Table 1. Data about sampling termines, localizations and waste materials

Tabela 1. Dane ogólne dotyczące terminów poboru prób, obiektów oraz rodzaju materiału

\begin{tabular}{lcc}
\hline $\begin{array}{c}\text { Localization } \\
\text { Lokalizacja }\end{array}$ & Obiects (kind of waste materials) & Date \\
Obiekty (rodzaje materiałów odpadowych) & Data \\
\hline 1 (B) & chicken feathers - pióra kurze & 30.01 .2015 \\
2 (P) & turkey feathers - pióra indycze & 05.03 .2015 \\
3 (D) & duck feathers - pióra kacze & 13.04 .2015 \\
& goose feathers - pióra gęsie & 11.05 .2015 \\
& slime - szlam & 21.05 .2015 \\
& biological sludge - osad z wirówki & 20.06 .2015 \\
& compost - kompost & 25.06 .2015 \\
& & 23.11 .2015 \\
& & 15.01 .2016 \\
\hline
\end{tabular}

\section{RESULTS AND DISCUSSION}

Based on achieved results it can be found that both tested materials and their origin are contaminated with microscopic fungi (Tables 2 and 3 ). The contamination amounted from about $160 \mathrm{cfu} \cdot 1 \mathrm{~g}^{-1} \mathrm{~d} . \mathrm{m}$. to $23 \cdot 10^{6} \mathrm{cfu} \cdot \mathrm{g}^{-1} \mathrm{~d} . \mathrm{m}$. average about $18 \cdot 10^{5} \mathrm{cfu} \cdot 1 \mathrm{~g}^{-1} \mathrm{~d} . \mathrm{m}$. According to many authors (Asaniyan et al. 2007; Wilkinson et al. 2011; Adedayo 2012), the poultry waste can contain pathogenic microorganisms, remains of drugs etc., which are harmful for crops, poultry, and for people and pests.

Table 2.Independence tests for variables: sampling time, object and localization Tabela 2. Testy niezależności dla zmiennych: data pomiaru, obiekt oraz ubojnia

\begin{tabular}{lccccc}
\hline $\begin{array}{l}\text { Variable } \\
\text { Zmienna }\end{array}$ & $\begin{array}{c}\text { Df } \\
\text { df }\end{array}$ & $\begin{array}{c}\text { Chi-square } \\
\text { Chi-kwadrat }\end{array}$ & $\begin{array}{c}\text { p-value } \\
\text { Wartość p }\end{array}$ & $\begin{array}{c}\text { G-square } \\
\text { G-kwadrat }\end{array}$ & $\begin{array}{c}\text { p-value } \\
\text { Wartość p }\end{array}$ \\
\hline Data - Data & 8 & 22.50000 & 0.004069 & 28.82659 & 0.000340 \\
\hline Object - Obiekt & 6 & 13.97143 & 0.029957 & 17.17288 & 0.008668 \\
\hline Localization - Ubojnia & 2 & 20.06250 & 0.000044 & 24.52436 & 0.000005 \\
\hline
\end{tabular}

Table 3. Descriptive statistics for investigated localizations (number in cfu $\cdot 1 \mathrm{~g}^{-1} \mathrm{~d} . \mathrm{m}$.)

Tabela 3. Statystyki opisowe dla badanych lokalizacji (liczebność w jtk $1 \mathrm{~g}^{-1}$ s.m.)

\begin{tabular}{lccccc}
\hline $\begin{array}{c}\text { Localization } \\
\text { Ubojnia }\end{array}$ & $\begin{array}{c}\text { N cases } \\
\text { N przypadków }\end{array}$ & $\begin{array}{c}\text { Mean } \\
\text { Srednia }\end{array}$ & $\begin{array}{c}\text { Minimum } \\
\text { Minimum }\end{array}$ & $\begin{array}{c}\text { Maximum } \\
\text { Maksimum }\end{array}$ & $\begin{array}{c}\text { Standard deviation } \\
\text { Odchylenie standardowe }\end{array}$ \\
\hline $1(\mathrm{~B})$ & 8 & 2928745 & 159 & 23138410 & 8166392 \\
\hline $2(\mathrm{P})$ & 2 & 7919145 & 2711 & 15835580 & 11195529 \\
\hline $3(\mathrm{D})$ & 15 & 361349 & 1857 & 4457953 & 1141652 \\
\hline
\end{tabular}

Scatter of results related to fungal contamination of materials was not uniform. In the case of feathers, it was the largest for duck and turkey, while small for chicken and goose. Considering other materials, the centrifuge sediment was characterized by quite large result scatter (Fig. 1 and 2). When analyzing particular localizations (slaughter houses), a great differentiation of results in slaughter houses No. $2(\mathrm{P})$ and No. $1(\mathrm{~B})$ was recorded, whereas in 
slaughter house No. 3 (D), it was much lower. Results achieved in subsequent test dates were characterized by very uniform scatter, except from two last ones, when both fungal contamination level and result scatter were considerably higher (Fig. 3).

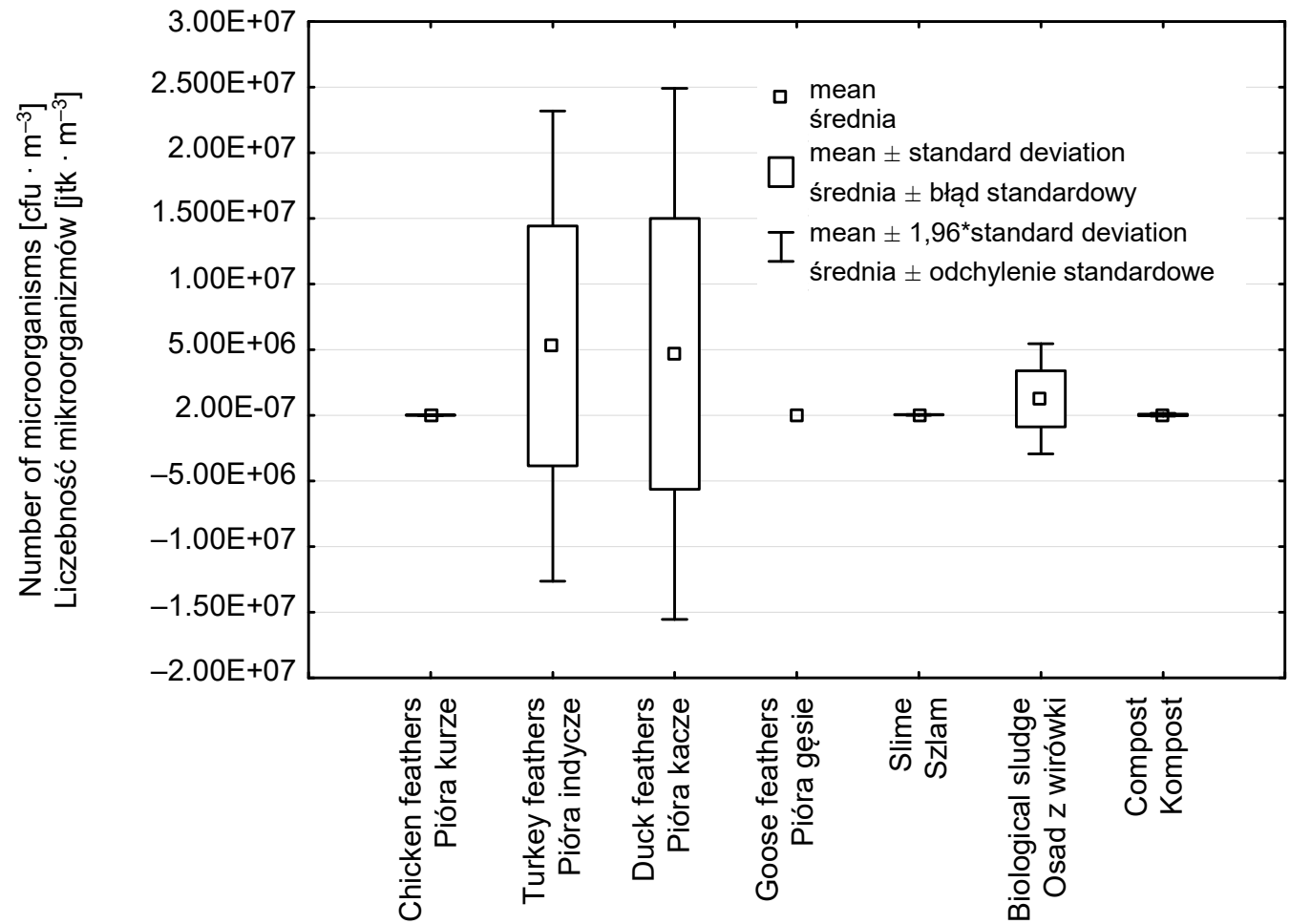

Fig. 1. Characterization of the distribution of fungi in the examined waste

Ryc. 1. Charakterystyka rozkładu liczebności grzybów w badanych odpadach

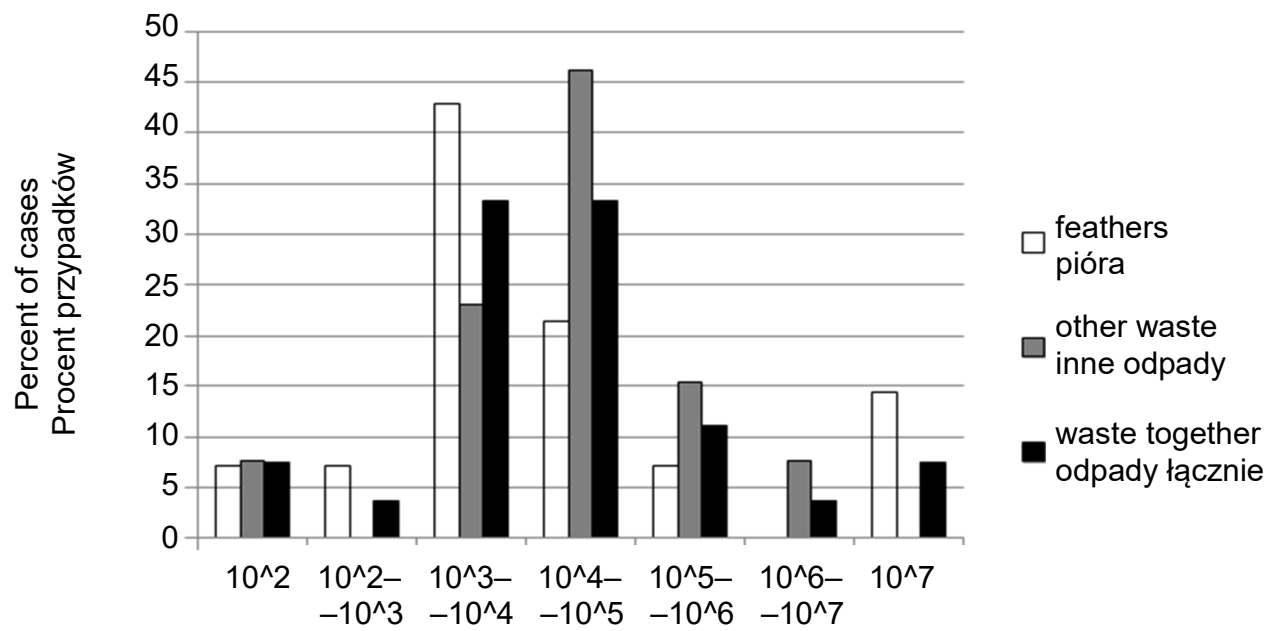

Range - Zakres

Fig. 2. Histogram for the results of measurements of the contamination of investigated materials with moulds

Ryc. 2. Histogram dla uzyskanych wyników zanieczyszczenia grzybami badanych materiałów 


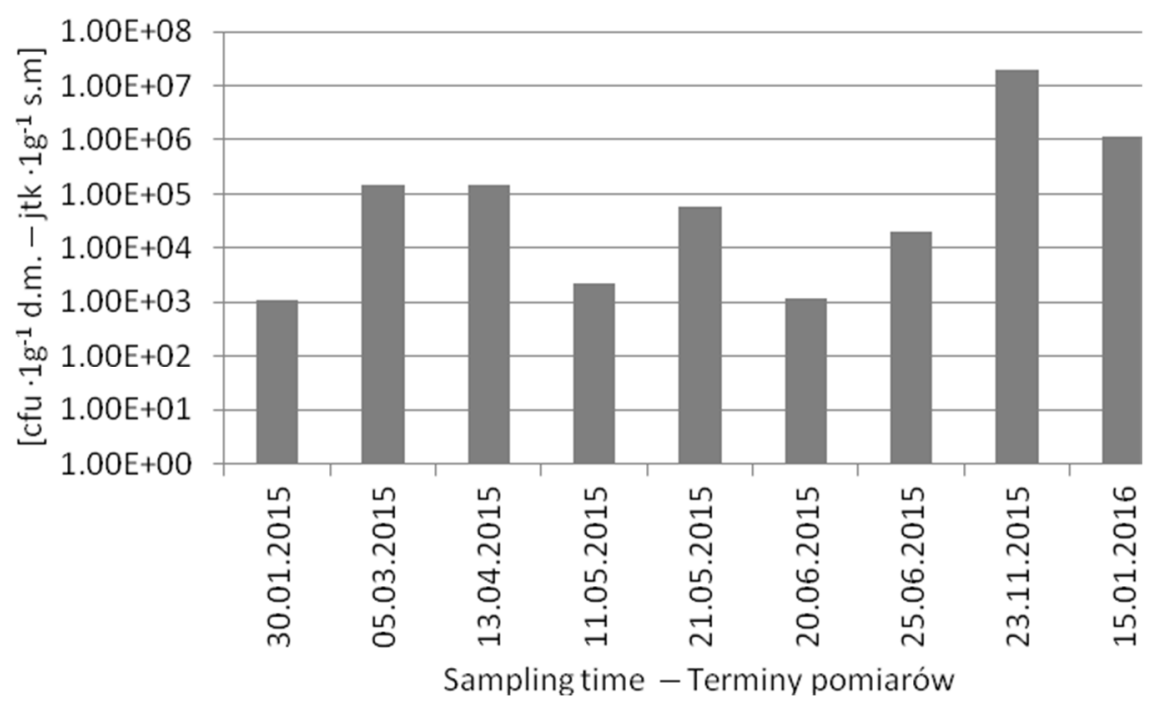

Fig. 3. Contamination of moulds samples in individual thermines

Ryc. 3. Zanieczyszczenie próbek grzybami w poszczególnych terminach

Highly significant differences in contamination degree values due to fungi were found. The independence tests also revealed the presence of significant differences between contamination values for dates, objects, and sampling localization (Tables 2 and 3).

The distribution of values of tested samples fungal contamination corresponded to Gauss curve: the largest number of measurements (20-45\%) reached values $10^{3}-10^{4}$ and $10^{4}-10^{5}$. Lower and higher values were recorded for much smaller number of cases (Fig. 2), which related both to contamination of feathers and other materials. However, for feathers, the largest number of results was grouped within the range of $10^{3}-10^{4}$, while other materials within $10^{4}-10^{5}$. It can be evidence that the latter were stronger contaminated with fungi. Fungal contamination is common at all poultry species, although less widespread than bacterial and viral ones. They cause remarkable economic loss in poultry industry due to their direct infectious nature or due to production of mycotoxins, which makes significant morbidity and mortality, namely at young birds, as well as growth inhibition, diarrhea, and fatal encephalitis (Singh et al. 2012; Grenier and Applegate 2013).

The largest fungal contamination was recorded for turkey feathers, average of about $8 \cdot 10^{6} \mathrm{cfu} \cdot 1 \mathrm{~g}^{-1}$ d.m. (Fig. 4.) (from $3 \cdot 10^{3} \mathrm{cfu} \cdot 1 \mathrm{~g}^{-1}$ d.m. to $15 \cdot 10^{6} \mathrm{cfu} \cdot 1 \mathrm{~g}^{-1} \mathrm{~d}$.m.). It exceeded results achieved at the initial step of measurements by almost four times.

The duck feathers contained from about $160 \mathrm{cfu} \cdot 1 \mathrm{~g}^{-1} \mathrm{~d}$.m. to about $23 \cdot 10^{6} \mathrm{cfu} \cdot 1 \mathrm{~g} \mathrm{~g}^{-1} \mathrm{~d} . \mathrm{m}$, with mean value of almost $6 \cdot 10^{6} \mathrm{cfu} \cdot 1 \mathrm{~g}^{-1} \mathrm{~d}$.m. Degree of the contamination decreased during the year with significant increase (about 100-fold) at the later stages.

Fungal contamination of chicken feathers was within the range from about $16 \cdot 10^{2} \mathrm{cfu} \cdot 1 \mathrm{~g}^{-1} \mathrm{~d} . \mathrm{m}$. to $33 \cdot 10^{3} \mathrm{cfu} \cdot 1 \mathrm{~g}^{-1} \mathrm{~d} . \mathrm{m}$., average $16 \cdot 10^{3} \mathrm{cfu} \cdot 1 \mathrm{~g}^{-1} \mathrm{~d}$.m., although at the initial period till March 2015, the contamination level was over one order lower than in further measurements. For goose feathers, the result was $2 \cdot 10^{3} \mathrm{cfu} \cdot 1 \mathrm{~g}^{-1} \mathrm{~d} . \mathrm{m}$. 


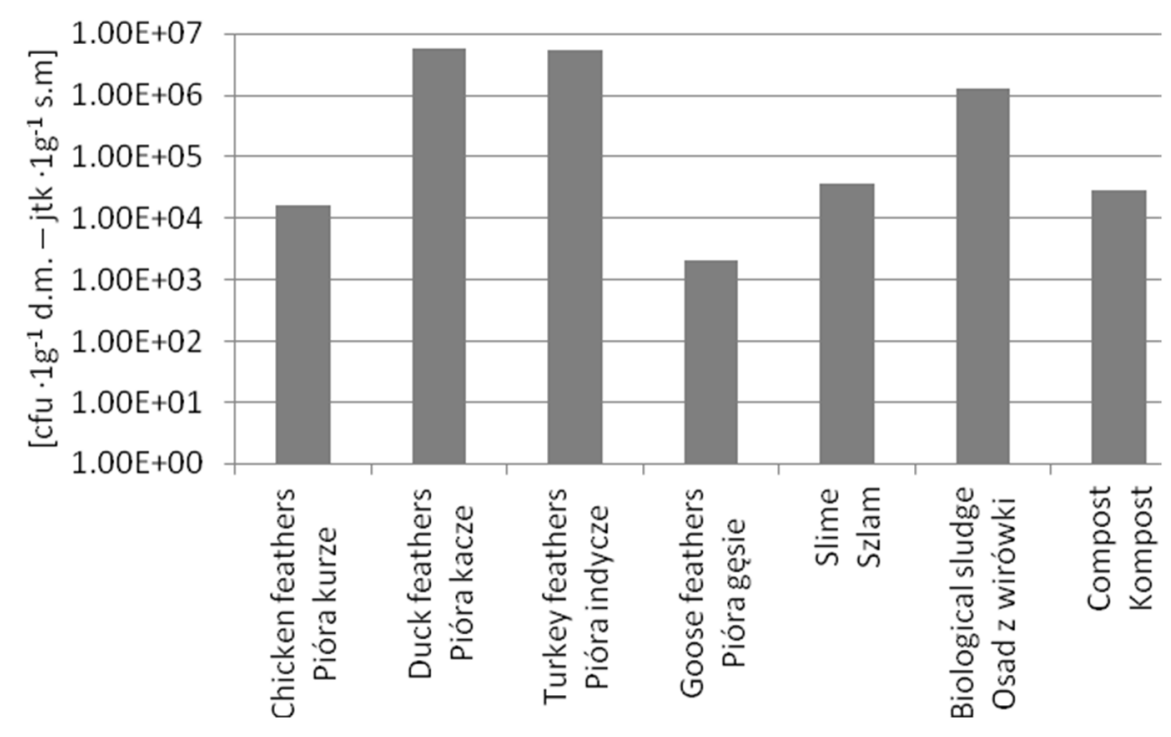

Fig. 4. Contamination of moulds samples in examined objects (materials and wastes) Ryc. 4. Zanieczyszczenie grzybami poszczególnych obiektów (materiałów i odpadów)

Among other materials, the largest fungal contamination degree was observed in sediment from centrifuge: from $26 \cdot 10^{3} \mathrm{cfu} \cdot 1 \mathrm{~g}^{-1} \mathrm{~d} . \mathrm{m}$. to about $45 \cdot 10^{5} \mathrm{cfu} \cdot 1 \mathrm{~g}^{-1} \mathrm{~d}$.m. with average value of almost $13 \cdot 10^{5} \mathrm{cfu} \cdot 1 \mathrm{~g}^{-1} \mathrm{~d} . \mathrm{m}$. The lowest contamination was recorded in the middle of measurement period. Sludge and compost contained much less count of fungi, respectively $23 \cdot 10^{3} \mathrm{cfu} \cdot 1 \mathrm{~g}^{-1} \mathrm{~d} . \mathrm{m}$. to $6 \cdot 10^{4} \mathrm{cfu} \cdot 1 \mathrm{~g}^{-1} \mathrm{~d} . \mathrm{m}$. (mean $37 \cdot 10^{3} \mathrm{cfu} \cdot 1 \mathrm{~g}^{-1} \mathrm{~d}$.m.) and $2 \cdot 10^{3} \mathrm{cfu} \cdot 1 \mathrm{~g}^{-1}$ d.m. to $1 \cdot 10^{5} \mathrm{cfu} \cdot 1 \mathrm{~g}^{-1}$ d.m. (mean $38 \cdot 10^{3} \mathrm{cfu} \cdot 1 \mathrm{~g}^{-1}$ d.m.). Nowadays, fungi are one of the most important cause of worldwide morbidity and mortality. The mould species include Cladosporium, Sporotrichum, Geotrichum, Penicillium and Mucor, while yeast species contain Candida spp., Cryptococcus spp., and Rhodotorula spp. (Dave and Ghaly 2011). Fungi were present at various sites depending on environmental conditions. They can cause a spectrum of diseases due to spores production. Fungal species the most often found during intoxication are mainly of five genera: Alternaria, Aspergillus, Cladosporium, Fusarium, and Penicillium. Other ones, including Chaetomium, Claviceps, Diplodia, Myrothecium, Phoma, Phomopsis, Pithomyces and Strachybotrys. These forms produce various toxic compounds, but not every isolate of the same species produce toxins (Cole et al. 2003; Brase et al. 2009). The analysis most often revealed the isolation of the following moulds: Aspergillus sp., Penicillium sp., Scopulariopsis sp., Trichoderma sp., Acremonium sp., Cephalosporium sp., Alternaria sp., Pithomyces sp., Eurotium sp., and yeast-like fungi: Rhodotorula sp., Candida sp., Yarrowia sp., and Saccharomyces sp.

Considering average values on the measurement dates (Fig. 3), the least fungal contamination was recorded on dates $1,4,6$, and 7 , in range slightly over $1 \cdot 10^{3} \mathrm{cfu} \cdot 1 \mathrm{~g} \mathrm{~g}^{-1} \mathrm{~d}$.m. The largest number of fungi was isolated on dates 8 and $9-$ about $2 \cdot 10^{6-7} \mathrm{cfu} \cdot 1 \mathrm{~g}^{-1} \mathrm{~d}$.m.

The change in seasons plays an important role in widespread of fungal contamination. Prevail of infections in summer and presence of fungi in poultry litter in autumn make that eradication is difficult (Soliman et al. 2009). Exposure to some fungi is harmful for human due to three specific mechanisms of the first generation of immune response such as allergy or 
pneumonia, second direct infection by fungal organism, and third toxic effect of irritant action on mold by-products such as mycotoxins (Adams et al. 1993; Bush et al. 2006).

Tested localization can be lined up referring to the increasing contamination of materials with fungi in a sequence: slaughter house No. 3 (D) $\left(40 \cdot 10^{4} \mathrm{cfu} \cdot 1 \mathrm{~g}^{-1} \mathrm{~d} . \mathrm{m}\right.$.), No. 1 (B) (3. $10^{6} \mathrm{cfu} \cdot 1 \mathrm{~g}^{-1} \mathrm{~d}$.m.), No. 2 (P) $\left(8 \cdot 10^{6} \mathrm{cfu} \cdot 1 \mathrm{~g}^{-1}\right.$ d.m.). Differences between slaughter houses result from conditions, animal slaughter technology, and waste management differences. Slaughter house No. 3 was the largest and the most modernized, while others were much smaller and more traditional.

\section{CONCLUSIONS}

1. Fungal contamination was found in all tested materials, in all slaughter houses, and on all measurement dates. Its variation was not subject to univocal dependencies during the year.

2. Scatter of results related to contamination of tested feathers was the largest for turkey and duck, and in the case of other materials, for sediment from centrifuge. The largest result scatter was recorded in slaughter houses No. $1(B)$ and $2(P)$, while in No. $3(D)$ it was slight.

3. Distribution of achieved contamination results corresponded to normal distribution with maximum at $10^{3}-10^{4}$ for feathers and at $10^{4}-10^{5}$ for other materials. Feather contamination with fungi increased in the sequence: goose, chicken, duck, and turkey. For other materials, it was: compost, sludge, centrifuge sediment.

4. Contamination of various origin materials differed between slaughter houses. The largest contamination of test materials with fungi was recorded in slaughter house No. 2 (P), the smallest in No. 1 (B), while the lowest level of contamination occurred in slaughter house No. 3 (D).

\section{REFERENCES}

Adams R., Kenneth B.K., Virginia A.I., Lawrence J.H., Roth G.W. 1993, Mold and mycotoxin problems in livestook feeding. Penn State University, Colleege of Agricultural Science, www.dairyweb.ca/ /Resources/USWebDocs/Mycotoxins2.pdf, access: 15.11.2017.

Adedayo V. 2012. Poultry waste management techniques in urban agriculture and its implications: A case of metropolitan Lagos, Nigeria. Asian J. Agric. Sci. 4(4), 258-263.

Al-Jamaien H.H., Ekeanyanwu R.C., Aruwayo A., Maigandi S.A., Malami B.S., Daneji A.I., Njoku S. 2013. Helminth parasites in the intestinal tract of indigenous chickens in Jordanian Villages. Pak. J. Nutr. 12 (3), 209-212.

Anne F. 2007. Poultry house management for alternative production, http://www.poultryinternational.digital.com, access: 15.11.2017.

Asaniyan E.K., Agbede J.O., Laseinde E.A.O. 2007. Impact assessment of different litter depths on the performance of broiler chicken raised on sand and wood shaving litters. World J. Zool. (2), $67-72$.

Ashwathanarayana R., Raja N. 2016. Prevalence of Keratinolytic Fungi Isolated from the Poultry waste sites around Shivamogga City, Karnataka, India. Int. J. Curr. Microbiol. App. Sci. 5(2), 344-358. DOI:http://dx.doi.org/10.20546/ijcmas. 2016 .502.040.

Brase S., Encinas A., Keck J., Nising C.F. 2009. Chemistry and biology of mycotoxins and related fungal metabolites. Chem. Rev. 109(9), 3903-4399. DOI: 10.1021/cr050001f.

Bush R., Portnoy J., Saxon A., Terr A., Wood R. 2006. The medical effects of mold exposure. J. Allergy Clin. Immunol. 117(2), 326-333. DOI: 10.1016/j.jaci.2005.12.001 
Cole R.J., Scheweikert M.A., Jarvis B.B. 2003. Handbook of secondary fungal metabolites. Vol. I-III. Amsterdam, The Netherlands, Academic Press,.

Dave D., Ghaly A.E. 2011. Meat spoilage mechanisms and preservation techniques: A critical review. Am. J. Agric. Biol. Sci. 6(4), 486-510.

Downes F.P., Ito K. 2001. Compendium of methods for the microbiological examination of foods. 4th ed. Washington, APHA.

Grenier B., Applegate T.J. 2013. Modulation of intestinal functions following mycotoxin ingestion: meta-analysis of published experiments in animals. Toxins 5(2), 396-430. DOI:10.3390/toxins5020396.

Kim J., Diao J., Shepherd M.W.J.r., Singh R., Heringa S.D., Gong C., Jiang X. 2012. Validating thermal inactivation of Salmonella spp. in fresh and aged chicken litter. Appl. Environ. Microbiol. 78(4), 1302-1307. DOI:10.1128/AEM.06671-11.

Moreki J.C., Charipasi S.C. 2011. Poultry waste management in Botswana: A review. J. Anim. Feed Res. 1(6), 285-292.

Musa I.W., Sai'du L., Adamu J. 2012. Outbreak of pod dermatitis (bumble foot) in broilers managed on deep litter in Zaria, Nigeria. Vet. Clin. Bull. J. Vet. Teaching Hospital. (in press).

Musa I.W., Sai'du L., Wakawa A.M., Ahmed J.S., Abdu P.A. 2009. Traumatic ventriculitis in layers managed on deep litter in Zaria, Nigeria. J. Vet. Teach. Hospital 2, 17-21.

Opara M.N., Osowa D.K., Maxwell J.A. 2014. Blood and gastrointestinal parasites of chickens and turkeys reared in the Tropical Rainforest Zone of Southeastern Nigeria. Open J. Vet. Med. 4(12), 308-313.

Singh S.D., Tiwari R., Dhama K. 2012. Mycotoxins and mycotxicosis - impact on poultry health and production: An overview. Poult. Punch. 28, 35-52.

Soliman E.S., Sobeih M.A.A., Ahmad Z.H., Hussein M.M., Abdel-Latiff H., Moneim A.A. 2009. Seasoneal epidemiological surveillance on bacterial and fungal pathogens in broiler farms in Egypt. Int. J. Polt. Sci. 8, 720-727. DOI:10.3923/ijps.2009.720.727.

Unal H.B., Bayraktar Ö.H., Alkan I., Akdeniz C.R. 2015. Evaluation possibilities of chicken manure in Turkey Scientific quarterly. J. Agric. Eng. 2(154), 5-14. DOI: http://dx.medra.org/10.14654/ir.2015.154.116.

Wilkinson K.G., Tee E., Tomkins R.B., Hepworth G., Premier R. 2011. Effect of heating and aging of poultry litter on the persistence of enteric bacteria. Poultry Sci. 90, 10-18.

\begin{abstract}
The poultry industry produces large amounts of waste that include solid waste and waste water. Although, numerous studies have been conducted on microbial associates with various stages related to poultry and meat products processing. Only a few studies have been reported on fungal exists of poultry wastes. The aim of this study investigation of fungi associated with different poultry wastes. The sample of poultry wastes included feathers, slime, biological sludge and compost. The samples were taken at various times in peroid from 2015-2016 from different poultry slaughter houses. Isolation of fungi was performed by serial dilution and plating methods on Rose Bengal Agar (RBA), medium supplemented with antibiotic. Identification of fungi was carried out by microscopic and genetic analysis $18 \mathrm{~S}$ ribosomal RNA gene. The number of fungi (cfu $\cdot \mathrm{g}^{-1}$ d.m.) were isolated from chicken and goose feathers $10^{3}-10^{4}$, from duck and turkey feathers even $10^{6}-10^{7}$, compost $10^{3}-10^{5}$, slime $-10^{4}$ and biological sludge $-10^{4}-10^{6}$. From the overall analysis, the dependence between the number of fungi and various type of samples and the season of taking the samples were found and type of poultry slaughter houses.
\end{abstract}

